\title{
Effect of thermal power plant effluent on the physico-chemical parameters of Thoothukudi coastal waters, South India
}

\author{
SHELARPIYUSHA SURESH, P. PADMAVATHY*, A. SRINIVASAN*AND K. KARAL MARX* \\ ICAR-Central Institute of Fisheries Education, Versova, Andheri (W), Mumbai - 400 061, Maharashtra, India \\ ${ }^{*}$ Fisheries College and Research Institute, Tamil Nadu Fisheries University, Thoothukudi - 628001 \\ Tamil Nadu, India \\ e-mail: padmarengan1968@yahoo.co.in
}

\begin{abstract}
The coolant water discharge area of a thermal power plant in Thoothukudi, Tamil Nadu was investigated to elucidate the changes in the coastal water and sediment quality characteristics. Water and sediment samples were collected from three different stations namely station I (about $900 \mathrm{~m}$ away from coolant water discharge point), station II (about $1250 \mathrm{~m}$ away from discharge point) and station III (about $1600 \mathrm{~m}$ away from discharge point) and analysed for the various physico-chemical parameters. The dissolved oxygen level increased with increasing distance from the discharge point i.e., from station I to III, whereas the temperature values showed decreasing trend. Concentration of ammonia, nitrite, nitrate and phosphate were found in the decreasing order from station I, II and III. Accumulation of heavy metals was in the order of $\mathrm{Al}>\mathrm{Fe}>\mathrm{Cu}>\mathrm{Zn}$ in the water samples and found slightly higher than the standards prescribed by European countries. The exchangeable phosphorus fraction appeared as the first major contributor among the different fractions of total sedimentary phosphorus. This study clearly explains that the effluent discharge in adjoining coastal waters affects the water and sediment quality.
\end{abstract}

Keywords: Ammonia, Coolant water, Heavy metals, Nitrite, Phosphorous

Effect of coolant water discharge in the adjacent coastal waters of marine environment is a major environmental crisis worldwide. The effect on coastal water would be more adverse in tropical zone where normal seawater temperature is near the upper tolerance limits of most marine organisms (Thorhaug, 1978). In addition, sea surface temperature increased during the $20^{\text {th }}$ century and continues to rise and from 1901 through 2015, temperature rose at an average rate of $0.13^{\circ} \mathrm{F}$ per decade (NOAA, 2016). The Tuticorin Thermal Power Plant (TTPP) is located at the southern part of the Thoothukudi Bay (08 46' 20" N; 78 10' 46” E) in the Gulf of Mannar along the south-east coast of India. The effluent discharge, mainly the fly ash, from TTPP, has already resulted in filling up of an extensive portion of the Bay that has caused irreversible damages to the ecosystem. Each boiler in the power station utilises about 750 cubic meter of seawater per hour for cooling and the effluent hot water is discharged into Thoothukudi Bay. The TTPP discharges effluent in the temperature range between 40 and $44^{\circ} \mathrm{C}$ into the adjacent water body at a rate of $115 \times 10^{6} 1$ day $^{-1}$ (Kailasam, 2004). The mixing of coolant water having elevated temperature with the coastal water would alter the physical, chemical and biological parameters of the coastal waters of Thoothukudi (Manimaran et al., 2002; Ananthan et al., 2005; Asha, 2010). Apart from these studies, no recent information is available on the physico-chemical characteristics and the seasonal variations in the water and sediment characteristics in response to effluent water discharge from TTPP. It is also highly essential to understand the extent of heavy metal pollution if any, released from the power plant.

The present investigation was carried out to analyse the physico-chemical characteristics of coastal waters receiving thermal power plant effluent discharge from TTPP. Water samples were collected from three different stations in Thoothukudi Bay viz., Station I; located at 900 m, Station II at $1250 \mathrm{~m}$ and Station III at $1600 \mathrm{~m}$ away from the coolant water discharge point of the power station. The study was carried out for a period of seven months.

Water samples were collected in clean labelled plastic containers without any air bubble. The water quality parameters such as $\mathrm{pH}$, salinity, dissolved oxygen, biological oxygen demand (BOD), chemical oxygen demand (COD), total dissolved solids (TDS) and nutrients such as nitrite, nitrate, ammonia and phosphate were analysed following standard procedures (Strickland and Parsons, 1968). Sediment samples were collected with the help of snapper and brought to the laboratory in polythene bags, dried at $60^{\circ} \mathrm{C}$ for $24 \mathrm{~h}$ and ground well as per Hall (1986). The dried sediment samples were sieved with plastic sieve having $<250 \mu \mathrm{m}$ pore size and subjected to further analysis. 
For heavy metal analysis, water samples were collected from the sampling stations in plastic containers, which were previously soaked in $1: 1 \mathrm{HNO}_{3}$ for $24 \mathrm{~h}$ to reduce potential sources of metal contamination (APHA, 1995). After arrival at the laboratory, samples were immediately filtered through membrane filter $(0.45 \mu \mathrm{m})$ into pre-washed plastic bottles and acidified to $\mathrm{pH}<2$ with $\mathrm{AR}$ grade concentrated $\mathrm{HNO}_{3}$. Then, the acidified samples were pre-concentrated using the synthetic chelating agent i.e. Ammonium Pyrdidin Dithio Carbonate (APDC-BHH spectrosol grade) and extracted with the organic solvent Methyl Isobutyl Ketone (MIBKAR extra pure) as per APHA (1995). The golden yellow coloured organic layer was aspirated in the fuel lean flame of air acetylene in Atomic Absorption Spectrophotometer. The concentration of metals such as copper $(\mathrm{Cu})$, zinc $(\mathrm{Zn})$ iron (Fe) and aluminium (Al) was measured.

All the statistical analyses were performed using SPSS 16.0 (SPSS Inc. Illinois). The physico-chemical characteristics of water, sediment and heavy metals were compared by one way analysis of variance. All mean separations were carried out by Duncan's Multiple Range Test at $\mathrm{p}<0.05$.

In the present study, the minimum temperature $\left(27.7^{\circ} \mathrm{C}\right)$ was recorded at station III and maximum temperature $\left(33.7^{\circ} \mathrm{C}\right)$ was noticed at station I due to discharge of coolant water directly to the station I, which is located just $900 \mathrm{~m}$ away from the discharge point. The mean temperature values obtained in station I, II and III were 30.5, 30.3 and $30.2^{\circ} \mathrm{C}$ respectively. Asha (2002) also reported maximum temperature of $38.9^{\circ} \mathrm{C}$ at the thermal power plant effluent discharge point in Thoothukudi. The minimum temperature of $27.7^{\circ} \mathrm{C}$ was recorded at station III which could be atributed to the inflow of rain water. This is also in agreement with the result of Selvin et al. (2010), who reported minimum temperature of $25^{\circ} \mathrm{C}$ at $1050 \mathrm{~m}$ away from the coolant water discharge point of TTPS.

The surface water $\mathrm{pH}$ ranged between 7.5 to 8.5 . There was not much variation in the $\mathrm{pH}$ between stations. The highest values of $\mathrm{pH}$ at station I, II and III were 8.4, 8.5 and 8.4 respectively. The results of the present study are in agreement with the observations made by Murugesan et al. (2011), who reported minimum $\mathrm{pH}$ value of 7.8 during post-monsoon season. The salinity range observed in the present study was comparable with that reported earlier in Thoothukudi coastal waters (Asha and Diwakar, 2007). The mean salinity values obtained in station I, II and III were $36.2,35.9$ and $36.4 \%$, respectively. The maximum salinity value of $39.9 \%$ was recorded at station I during May, which could be due to the evaporation of seawater.

The mean dissolved oxygen values obtained in station I, II and III were 3.3, 3.6 and $3.7 \mathrm{mg} \mathrm{l}^{-1}$, respectively. A rise of $10^{\circ} \mathrm{C}$ in temperature reduces the solubility of oxygen by
$20 \%$. The dissolved oxygen value increased from station I $\left(1.5 \mathrm{mg} \mathrm{l}^{-1}\right)$ to station III $\left(5.7 \mathrm{mg} \mathrm{l}^{-1}\right)$, while the temperature decreased with increasing distance from discharge point. This shows that the temperature is affecting the dissolved oxygen level in water. Selvin et al. (2010) also reported increased dissolved oxygen level with increase in distance from coolant water discharge point of the power station and the range observed was 3.7-6.1 $\mathrm{mg} \mathrm{l}^{-1}$. The monthly variations in the water quality parameters at three different stations are depicted in Fig.1.

The maximum nitrite value of $4.1 \mathrm{~g} \mathrm{~g}^{-1}$ during March and the minimum of $0.4 \mu \mathrm{g} \mathrm{l}^{-1}$ was recorded during May in station I and III, respectively. Higher nitrite values were recorded during post-monsoon season, due to oxidation of ammonia, reduction of nitrate, recycling of nitrogen and bacterial decomposition of planktonic detritus and also due to denitrification. The surface water nitrate was recorded in the range between 0.040 to $0.160 \mu \mathrm{g} \mathrm{NO}_{3}-\mathrm{N} \mathrm{l}^{-1}$. The lowest values of the nitrate at station I, II and III were $0.042,0.040$ and $0.040 \mu \mathrm{g} \mathrm{NO}_{3}-\mathrm{N} \mathrm{l}^{-1}$, respectively. In the present study, the maximum ammonia value of $390.4 \mu \mathrm{g}^{-1}$ was observed during November and minimum of $54.4 \mu \mathrm{g}^{-1}$ during May in station II. The maximum value of ammonia could be attributed to the land run off. Sekar et al. (2009) also reported the highest ammonia value of $654 \mu \mathrm{g} \mathrm{I}^{-1}$ in fishing harbour of Thoothukudi which was attributed to raw sewage and effluent discharge. In the present investigation, the mean values of phosphate obtained in station I, II and III were $3.9 \pm 0.048, \quad 3.4 \pm 0.041$ and $3.2 \pm 0.049 \mu \mathrm{g} \quad \mathrm{PO}_{4}-\mathrm{P} \quad \mathrm{l}^{-1}$, respectively. The maximum phosphate value of $6.6 \mu \mathrm{g}$ at. $\mathrm{l}^{-1}$ was observed during April in station I, which could be due to the river run off from Korampallam Creek (Selvin, 2010). The mineralisation at high temperature results in quicker degradation of organic matter and consequent release of soluble phosphorus. The low value observed in summer might be due to the limited flow of freshwater, high salinity and utilisation of phosphate by phytoplankton (Bragadeeswaran et al., 2007).

The mean BOD values recorded were 2.4, 2.7 and $2.4 \mathrm{mg} \mathrm{l}^{-1}$ at station I, II and III respectively. The high temperature in station I would have caused increased oxygen demand resulting in decreased oxygen level. Surface water COD was recorded in the range between 2.8 to $11.0 \mathrm{mg} \mathrm{l}^{-1}$. The COD values were lower $\left(11.0 \mathrm{mg} \mathrm{l}^{-1}\right)$ than the acceptable limit (250 $\left.\mathrm{mg} \mathrm{l}^{-1}\right)$. Maximum TDS level (29.10 ppm) was recorded in station I which may be due to turbulence of coolant water and leaching of suspended solids from ash pond. The minimum TDS value (12.40 ppm) was observed at station III, which might be due to the less suspended solids resulting from increase in distance from fly ash pond.

The concentration of copper in the surface water was recorded in the range between 0.021 to $0.083 \mathrm{mg} \mathrm{l}^{-1}$. The 


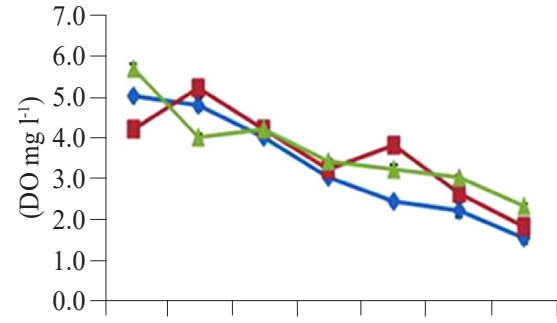

(a)

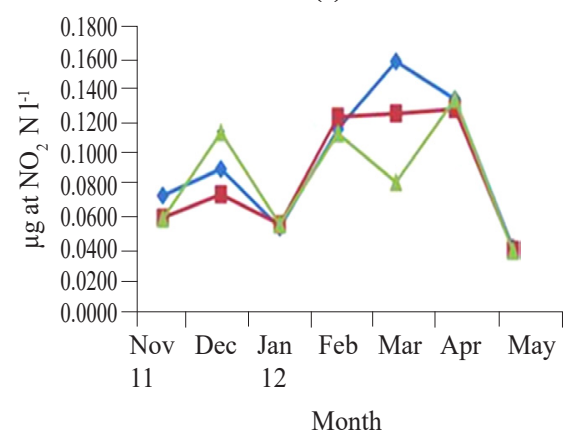

(d)

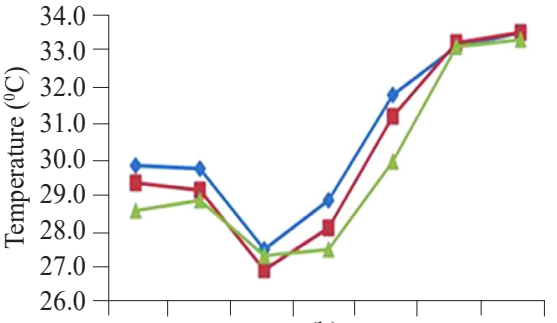

(b)

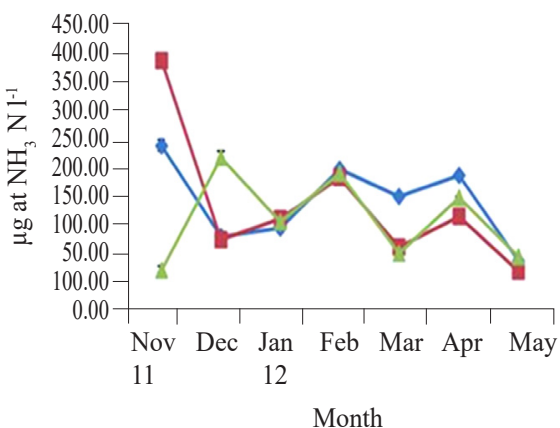

(e)

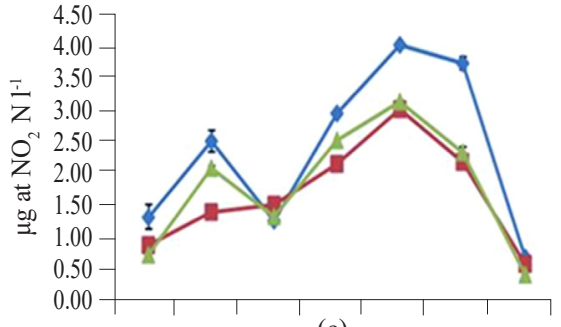

(c)

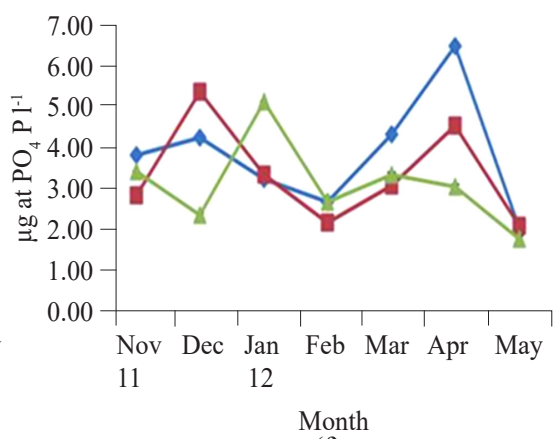

(f)

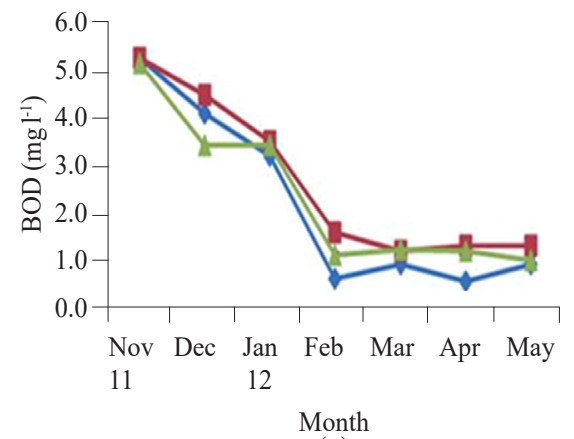

(g)

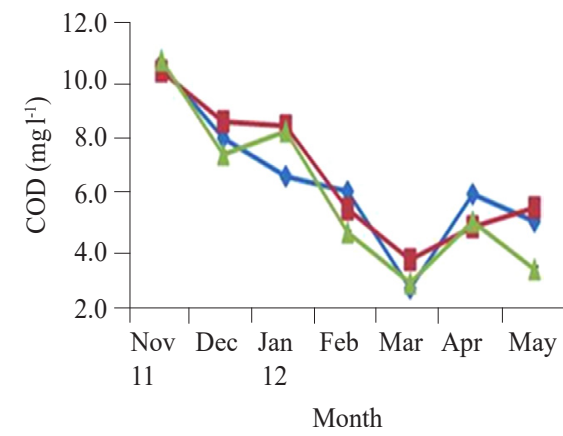

(h)

Fig. 1. Monthly variation in the water quality parameters recorded at the three different sampling stations. (a) Dissolved oxygen, (b) Water temperature, (c) Nitrite-N, (d) Nitrate-N, (e) Ammonia-N, (f) Phospours P, (g) BOD, (h) COD

mean values of copper obtained in station I, II and III were $0.046 \pm 0.001,0.042 \pm 0.001$ and $0.039 \pm 0.001 \mathrm{mg} \mathrm{l}^{-1}$, respectively (Fig. 2). This is in agreement with Sarode et al. (2010) who reported copper value of $0.052 \mathrm{mg} \mathrm{l}^{-1}$ in well water near ash pond of thermal power plant in Maharashtra.

In the present study, the concentration of zinc in the surface water was recorded in the range between 0.013 to $0.077 \mathrm{mg} \mathrm{l}^{-1}$ and the concentration was slightly higher than the earlier reports. Murugesan et al. (2011) reported a value of $0.4 \mathrm{mg} \mathrm{l}^{-1}$ at $1000 \mathrm{~m}$ away from TTPS. Nalawade et al. (2012) also reported concentration of $4.66 \mathrm{mg} \mathrm{l}^{-1}$ in Parli Thermal Power Station, Maharashtra.

The concentration of iron in the surface water was recorded in the range between 0.42 to $5.25 \mathrm{mg} \mathrm{l}^{-1}$. The lowest and highest values of the ferrous iron concentration at station I, II and III were 0.42 and 1.46, 0.34 and 2.72 and 0.47 and $5.25 \mathrm{mg} \mathrm{l}^{-1}$, respectively. Saravanan (1997) reported iron concentration of $0.021 \mathrm{mg} \mathrm{l}^{-1}$ and aluminium concentration of $0.023 \mathrm{mg} \mathrm{l}^{-1}$ in the area near to fly ash pond of TTPS. In the present study, the concentration of aluminium in the water sample was recorded in the range between 0.20 to $6.75 \mathrm{mg} \mathrm{l}^{-1}$.

European countries have promulgated standards for copper and zinc at 0.005 and $0.04 \mathrm{mg} \mathrm{l}^{-1}$, respectively to protect salt water fish and shellfish (Moore, 1991). The concentrations of these heavy metals recorded in water during the present study were found slightly higher than the standards prescribed by European countries. The higher levels recorded in all the three stations could be attributed to the discharge of thermal effluent. There was significant deference between the heavy metal concentrations among the three different stations $(p<0.05)$. The results of the present study revealed that, the metals were accumulated in the order $\mathrm{Al}>\mathrm{Fe}>\mathrm{Cu}>\mathrm{Zn}$ in the study area. 


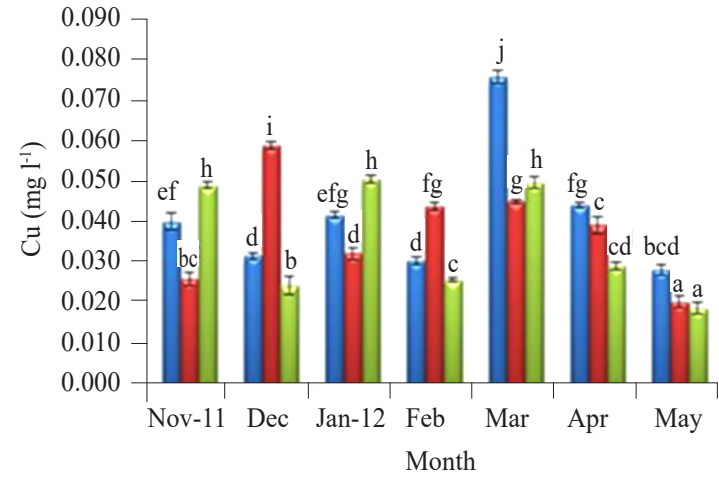

(a)

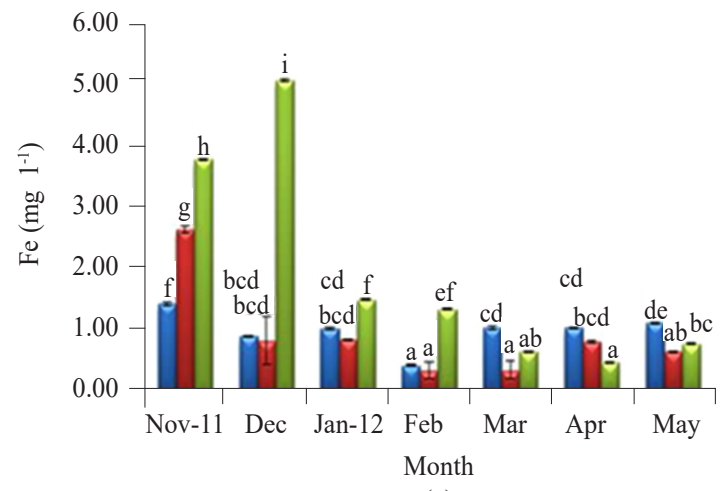

(c)

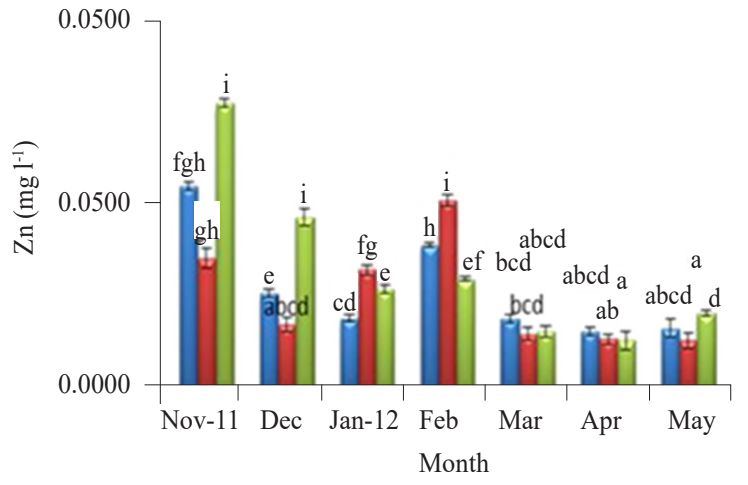

(b)

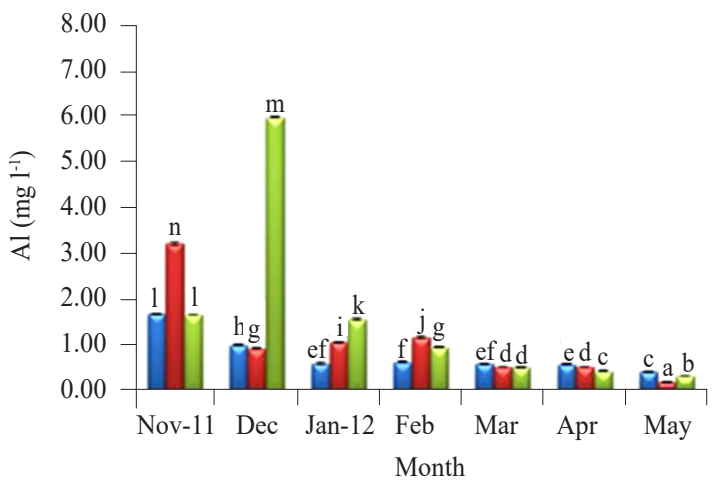

(d)

घ Station 1, घ Station 2, घ Station 3

Fig. 2. Monthly variation in the level of heavy metals in the surface water at three different sampling stations (values are mean $\pm \mathrm{SE}$ ). (a) Copper, (b) Zinc, (c) Iron, (d) Aluminium

Sedimentary organic matter was recorded in the range between 29.0 to $87.0 \mathrm{mg} \mathrm{g}^{-1}$. The mean values obtained in station I, II and III were $70.4 \pm 0.063,56.8 \pm 0.060$ and $49.0 \pm 0.051 \mathrm{mg} \mathrm{g}^{-1}$, respectively (Fig. 3). The maximum value of $87.0 \mathrm{mg} \mathrm{g}^{-1}$ was observed in station I which could be attributed to high clay content and also high amount of effluent discharge from thermal power plant. The total sedimentary phosphorus content was in the range between 3.59 to $9.95 \mu \mathrm{g} \mathrm{PO}_{4}-\mathrm{P} \mathrm{g}^{-1}$. The maximum value of $9.95 \mu \mathrm{g} \mathrm{g}^{-1}$ was observed in station I, being the area which receives high amount of discharge from thermal plant. The level of exchangeable phosphorus fraction ranged between 3.93 to $9.71 \mu \mathrm{g} \mathrm{PO}_{4}-\mathrm{P} \mathrm{g}^{-1}$. The mean values obtained in station I, II and III were $8.25 \pm 00.048$,

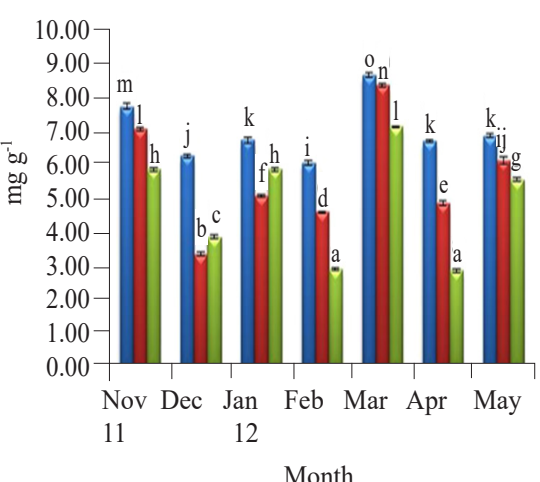

(a)

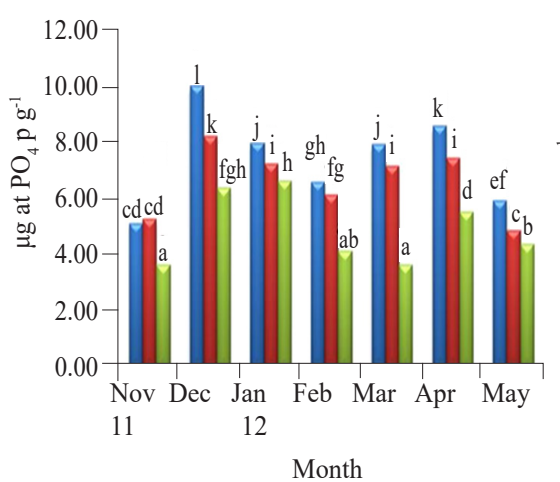

(b)

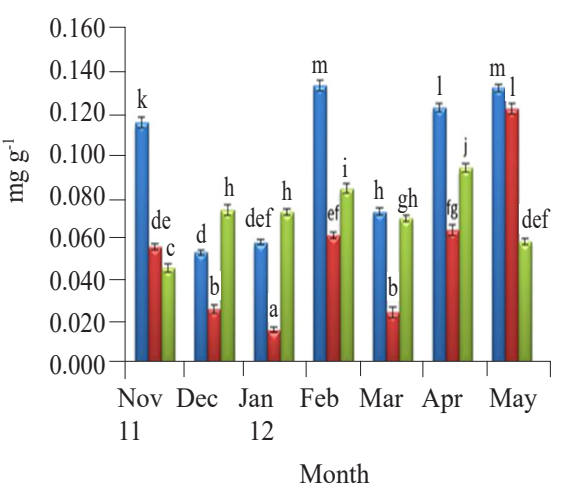

(c)

- Station 1, a Station 2, - Station 3

Fig. 3. Monthly variations in the sediment characteristics at three different sampling stations. (a) Total sedimentary organic matter, (b) Total sedimentary phosphorous, (c) Total sedimentary nitrogen 
$7.04 \pm 0.039$ and $6.27 \pm 0.041 \mu \mathrm{g} \mathrm{PO}_{4}-\mathrm{P} \mathrm{g}^{-1}$, respectively. The exchangeable fraction of sedimentary phosphorus appeared as the first major contributor to the total sedimentary phosphorus. The phosphorus bound to $\mathrm{Fe}-\mathrm{Mn}$ oxide fraction content was recorded in the range between 4.4 to $9.5 \mu \mathrm{g}$ at $\mathrm{PO}_{4}-\mathrm{P} \mathrm{g} \mathrm{g}^{-1}$. This fraction of sedimentary phosphorus appeared as the second major contributor to the total sedimentary phosphorus.

The apatite phosphorus fraction of sediment was recorded in the range between 1.90 to $8.73 \mu \mathrm{g}$ at $\mathrm{PO}_{4}-\mathrm{P} \mathrm{g}^{-1}$. This fraction of phosphorus was the third contributor to total sedimentary phosphate in all the stations. This fraction of sedimentary phosphorus cannot be utilised by algae (Ishio and Kondo, 1980) and least affected by hydrogen sulphide (Ishio et al., 1986). In thermal effluent, this fraction of sedimentary phosphate is not produced separately but, other than this waste water may carry apatite without causing any change in its concentration. The total sedimentary nitrogen varied between 0.016 to $0.135 \mathrm{mg} \mathrm{g}^{-1}$. These values were high during summer in all the three stations due to the oxidation of dead plant organic matter, which settled on the top layer. The lower value of total nitrogen during monsoon season may be ascribed to low level of organic matter. Significant difference was recorded between the physico-chemical parameters of water and sediment samples among the three different stations $(\mathrm{p}<0.05)$.

In thermal power plants, ash formed during combustion of coal and effluent is mixed with water and is discharged in slurry form in ash disposal ponds. The present study clearly explains that, effluent discharge in adjoining coastal waters affects the physico-chemical parameters of water and sediments.

\section{References}

Ananthan, G., Sampathkumar, P., Soundarapandian, P. and Kannan, L. 2005. Heavy metal concentrations in Ariyankuppam Estuary and Verampattinam coast of Pondicherry. Indian J. Fish., 52: 501-506.

APHA 1995. Standard methods for the examination of water and wastewater, $19^{\text {th }}$ edn., American Public Health Association, Washington, DC, USA.

Asha, P. S., Krishnakumar, P. K., Kaladharan, P., Prema, D., Diwakar, K., Valsala, K. K. and Bhat, G. S. 2010. Heavy metal concentration in seawater, sediment and bivalves off Tuticorin. J. Mar. Biol. Ass. India, 52(1): 48-54.

Asha, P. S. 2002. Impact of effluent discharge from Tuticorin thermal power plant, Tuticorin on the hydrological conditions Tuticorin Bay. Proceedings of the DAE BRANS National Seminar on Thermal Ecology, p. 150-156.

Asha, P. S. and Diwakar, R. 2007. Hydrobiology of the inshore waters off Tuticorin in the Gulf. J. Mar. Biol. Ass. India, 49: 7-11.
Bragadeeswaran, S., Rajasegar, M., Srinivasan, M. and Kanagarajan, U. 2007. Sediment texture and nutrients of Arasalar Estuary, Karaikkal, South-east coast of India. J. Environ. Biol., 28: 237-240.

Hall, L. V. 1986. The effect of dredging and reclamation on metal levels in water and sediment from an estuarine environment off Trinidad, West Indies. Environ. Pollut., 56: 189-207.

Ishio, S. and Kondio, K. 1980. Study on the scarcity of red tide in the eutrophicated waters of Ariak Bay-1. Dissolution of phosphorus ion from bottom mud by hydrogen sulphide. Bull. Japan Soc. Sci. Fish., 46(8): 977-989.

Ishio, S., Kuwahara, M. and Nakagawa, 1986. $\mathrm{H}_{2} \mathrm{~S}$ extraction method for Fe-bound phosphorus in sea sediments. Bull. Japan. Soc. Sci. Fish., 52(1): 103-108.

Kailasam, M. 2004. Effect of thermal effluent discharge on benthic fauna off Tuticorin Bay, South-east coast of India. Indian J Mar. Sci., 33(2): 194 -201.

Manimaran, B., Ramadhas, V. and Santhanam, R. 2002. Metal pollution in Tuticorin coastal waters due to fly ash of thermal power plant. Proceedings of the National Seminar on Marine and coastal ecosystems: Coral and mangrove-problems and management strategies. SDMRI Res. Publ., 2: 190-193.

Moore, J. W. 1991. Inorganic contaminants of surface water, research and monitoring priorities. Springer Verlag, New York. 334 pp.

Murugesan, P., Muniasamy, M. and Muthuvelu, S. 2011. Utility of benthic diversity in assessing the health of an ecosystem. Indian J. Geo-Mar. Sci., 40(6): 783-793.

Nalawade, P. M., Bholay, A. D. and Mule, M. B. 2012. Assessment of groundwater and surface water quality indices for heavy metals nearby Area of Parli Thermal Power Plant. Univers. J. Environ. Res. Technol., 1: 47-51.

NOAA 2016. Climate change indicators: sea surface temperature National Centers for Environmental Information National Oceanic and Atmospheric Administration, www.ncdc. noaa.gov/data-access marineocean-data/extended-reconstructedsea-surface-temperature-ersst (Accessed March 2016).

Saravanan, R. 1997. Fly ash induced heavy metal pollution in Tuticorin coastal waters. M. F. Sc. Thesis, Fisheries College and Research Institute, Tamil Nadu Veterinary and Animal Sciences Univeristy, Chennai, 75 pp.

Sarode, D., Ramanand, J. and Vasimshaikh, K. 2010. Extraction and leaching of heavy metals from thermal power plant fly ash and its admixtures. Polish J. Environ. Stud., 19(6): 1325-1330.

Saravanan, R. 1997. Fly ash induced heavy metal pollution in Tuticorin coastal waters. M. F. Sc. Thesis, Fisheries College and Research Institute, Tamil Nadu Veterinary and Animal Sciences Univeristy, Chennai 75 pp.

Sekar, P., Poongothai, S. and Neelakantan, M. A. 2009. Impact of industrial pollution on the physicochemical characteristics 
of sea water in Thoothukudi coastal area, Res. J. Chem., 2(4): 912-919.

Selvin, P., Ananthan, G. and Sudhakar, M. 2010. Studies on the effect of coolant water effluent of Tuticorin thermal power station on hydrobiological characteristics of Tuticorin coastal waters, South-east coast of India. Curr. Res. J. Biol. Sci., 2(2): $118-123$
Strickland, J. D. H and Parson, T. R. 1968. A pratical handbook of seawater analysis. Bull. Fish. Res. Bd. Canada, 167: 311 pp.

Thorhaug, A. 1978. The effect of heated effluent from power plants on sea grass (Thalassia) communities quantitatively comparing estuaries in the subtropics to the tropics. Mar. Pollut. Bull., 9: 181-187. 